\title{
ESTABLISHING AFRICOM: PRESSING QUESTIONS, POLITICAL CONCERNS AND FUTURE PROSPECTS
}

\author{
Prof Theo Neethling ${ }^{1}$ \\ Department of Political Science (Mil.) \\ Faculty of Military Science, Stellenbosch University
}

\section{Introduction}

In the post-Cold War period, Africa did not constitute a top strategic priority for the U.S. A 1995 report by the Department of Defence (DoD) listed Africa at the bottom of the world's regions in strategic terms. In 1998, the National Security Strategy of the U.S. confirmed that America's security interests with regard to Africa were limited. Hence the tendency in the past was to relegate Africa to the periphery of American strategy. ${ }^{1}$

However, as Metz rightly argued some years ago, such an approach would not be wise: the U.S. does indeed have strategic interests in Africa. After all, from a U.S. point of view, serious transnational threats emanate from the region, including: state-sponsored terrorism, narcotics trafficking, weapons proliferation, international crime, environmental damage, and pandemic disease. Furthermore, Africa has been the scene of recurrent humanitarian crises, often as a result of intra-state armed conflict.

This suggests that the United States should remain in Africa but do so in a way that generates the maximum effectiveness from every effort. Clearly promotion of political and economic reform must be at the centre of American policy. But security cannot be overlooked. $^{2}$

The Bush Administration's National Security Strategy of 2002 indicated a need for a more focused approach towards Africa: "In Africa, promise and

\footnotetext{
${ }^{1}$ The author owes thanks to the reviewers for some critical comments and thoughtful insights; some of which have been worked into the article.
} 


\section{2}

opportunity sit side by side with disease, war, and desperate poverty. This threatens both a core value of the United States - preserving human dignity - and our strategic priority - combating global terror." The Administration's 2006 National Security Strategy went even further, identifying Africa as "a high priority for this Administration" and recognising that American security depends on partnering with Africans to strengthen fragile and failing states and to bring so-called ungoverned areas $^{3}$ under the control of effective democracies. ${ }^{4}$

This said, on 6 February 2007, the Bush Administration announced its intention to create a new unified combatant command, U.S. Africa Command, or AFRICOM, to promote U.S. national security objectives in Africa and its surrounding waters. ${ }^{5}$ This announcement followed years of discussions within the DoD about the merits of some kind of African Command. ${ }^{6}$ The aim of AFRICOM is to strengthen U.S.-African security co-operation and to create new opportunities to bolster the capabilities of Africa role-players ${ }^{7}$ - all of which brought a new dimension to U.S. strategic interests in Africa.

With the advent of the Pentagon's new AFRICOM, it appears as if U.S. foreign and security policies regarding the African continent are in a major period of flux. It appears to be moving towards greater engagement with African roleplayers. ${ }^{8}$ However, this interest in Africa and related developments concerning the creation of AFRICOM sparked a vocal reaction and some critical questions and remarks from defence and security analysts and other observers in Africa about 'renewed interest' by the U.S. in Africa. Moreover, it has also elicited some heated responses from political role-players on the African continent. Swart refers to the responses as a mixture of anticipation, trepidation, suspicion, scepticism and condemnation. He correctly points out that a number of pitfalls are already emerging in the run-up to the establishment of this command initiative, which reflect that African governments are wary of being too closely aligned with Washington. ${ }^{9}$ In view of the above, this article intends to highlight, discuss and reflect on some of the strategic considerations, concerns from African observers, pressing questions and future prospects concerning the establishment of AFRICOM.

\section{Establishing AFRICOM}

Up to the present, U.S. military involvement in Africa has been shared among the U.S. European Command (EUCOM), the U.S. Central Command (CENTCOM) and the U.S. Pacific Command (PACOM). EUCOM is responsible for the largest swath of the continent, namely North Africa, West Africa and central and southern Africa. CENTCOM covers the Horn of Africa, including Somalia, Ethiopia, Eritrea, 
Kenya, Djibouti, Sudan, Egypt and the Seychelles. PACOM is responsible for Madagascar and the Indian Ocean area off the African coast. Given the fact that Africa has been subsumed under other regional commands, the continent has never really been a priority for the U.S. military. In the words of Susan Rice, former U.S. Assistant Secretary of State for African Affairs: "Africa has been divided up and been the poor stepchild in each of these different commands and not gotten the full attention it deserves". 10

Against this background the establishment of AFRICOM is linked to the transfer and geographical responsibility for Africa from the above commands. Having been established as a sub-unified command towards the end of 2007, AFRICOM is currently still subordinate to EUCOM. After achieving full operational capability in October 2008 as a stand-alone unified Command, the commander of AFRICOM will report to the Secretary of Defence, like all other unified commanders in the DoD. ${ }^{11}$ In eyes of the Pentagon and of the command structures, this will effectively put Africa on a par with the Pacific Rim, Europe, Latin America, the Middle East and North America. ${ }^{12}$ Meanwhile, AFRICOM's transition team will use existing facilities at Kelley Barracks, Stuttgart, Germany. The plan is to eventually place the headquarters in Africa, and American officials are consulting with strategic partners in Africa to identify a suitable location for the Command's headquarters. The headquarters staff will be tailored to accomplish the commands mission ${ }^{13}$ and there is no plan to have a significant troop presence on the African continent.

In an article in Military Review of January-February 2008, the question is rightly asked: "Why AFRICOM?" This question boils down to three subsidiary issues: ${ }^{14}$

- Africa was never a number one priority for any unified command.

- $\quad$ Owing to historical disinterest in the continent, the DoD never developed a sizable cadre of dedicated African experts.

- Africa has never benefited from the advocacy of a four-star commander whose undiluted mandate includes helping policymakers understand the perspectives of African countries.

In view of the above, the rationale behind the creation of AFRICOM is of particular interest. According to testimony by a former Commander of EUCOM, General James Jones, to the Senate Armed Services Committee in 2006, EUCOM's staff is now spending more than half their time on Africa issues, in stark contrast to previous years. More recently, it was testified that the increasing strategic significance of Africa will continue to pose the greatest security stability challenge 


\section{4}

to EUCOM. Specifically, the "large ungoverned area" in Africa, HIV/AIDS, corruption, weak governance and poverty throughout the continent are perceived as key factors in the security stability issues that affect every African state. Hence, members of Congress have expressed an interest in the creation of an African Command, and in 2006, Senator Russ Feingold introduced legislation requiring a feasibility study on the establishment of AFRICOM. ${ }^{15}$

According to Rear Admiral Robert Moeller, who has been appointed Executive Director of AFRICOM, the DoD is creating the Command as Africa is growing in military, strategic and economic importance in global affairs. The U.S. is, therefore, seeking more effective ways for the DoD to help prevent and respond to humanitarian crises, improve co-operative efforts to stem transnational terrorism and to sustain enduring efforts that will contribute to African unity and bolster security on the African continent. ${ }^{16}$ AFRICOM's mission is, therefore, intended to promote U.S. strategic objectives by working with African states and regional organisations, such as the African Union (AU), to help strengthen stability and security on the continent through improved security capability, military professionalism and accountable governance. The Command's military operations would aim to deter aggression and respond to crises. ${ }^{17}$ Importantly, Africa's growing strategic importance to U.S. strategic interests is clearly acknowledged. This relates to

... Africa's role in the Global War on Terror and the potential threats posed by ungoverned spaces (e.g. failed states); the growing importance of Africa's natural resources, particularly energy resources; and ongoing concern for the continent's many humanitarian crises, armed conflicts, and more general challenges, such as the devastating effect of HIV/AIDS. ${ }^{18}$

Of particular interest is that AFRICOM will seek interagency coordination with the State Department, USAID and other government agencies, and that it will have a larger non-DoD civilian staff than the other combatant commands. Non-DoD civilian staff positions will include senior leadership positions, senior advisors and subject experts. A senior U.S. diplomat, Ambassador Mary Carlin Yates, was even appointed as Deputy to the Commander for civil-military activities. As such, Yates is the first non-DoD civilian to be integrated into the command structure of a unified command. She will be responsible for co-ordination of the command's activities with other U.S. government agencies and furthermore be overseeing the implementation and execution of AFRICOM's programmes and operations. ${ }^{19}$ All of this seems to imply that AFRICOM will execute the traditional tasks of other U.S. commands, but execute this in a context of interagency co-operation to ensure an 


\section{5}

approach that would go beyond the traditional paradigm. Rather than focusing on "war-fighting", AFRICOM will focus on "war prevention", according to the first AFRICOM commander, Army General William E. (Kip) Ward. ${ }^{20}$ In fact, planners show considerable interest in "soft power" issues such as health, infrastructural rehabilitation, the environment, economic development, security-sector reform, conflict attenuation, and other human-security angles. ${ }^{21}$

Finally, there was much speculation about a possible headquarters location. Some raised the point that Morocco is the only geographically and politically viable location for headquartering AFRICOM because it is a neutral Muslim state that has proved itself willing to work with the U.S. to combat the growth of radical Islam in Africa. In addition, it was felt that there could be some lesser placement in the Gulf of Guinea, east Africa and southern Africa. Others suggested Addis Ababa, Ethiopia, as a viable location for the headquarters because it is the AU seat, and the U.S. entertains good relations with the Ethiopian government. ${ }^{22}$

\section{Reaction and concerns}

Many critical questions about AFRICOM have been posed in recent times and these questions are not confined to African observers and analysts. Robert Munson, a major in the U.S. Air Force Reserve and currently serving an active duty tour as Assistant Professor of Comparative Military Studies at the U.S. Air Command and Staff College, boldly asks: "Break things or help. This is a significant question in light of the formation of the new Africa Command". ${ }^{23}$ Such questions, it is argued, should be viewed against the need for the U.S. to return to the American image produced after World War II, when the world did not see the U.S. as a conquering behemoth, intent on imposing its views on the rest of the world, but instead as a country willing to work multilaterally to solve the world's problems. ${ }^{24}$

More importantly, the announcement concerning the creation of AFRICOM sparked quite a vocal response from African commentators. For instance, Mark Malan, a South African currently operating in Washington DC, points out that a quick glance at the titles of recent articles on AFRICOM in the African press indicates that the Command is perceived as a threat. In a testimony before the Subcommittee on African Affairs of the Committee on Foreign Relations of the U.S. Senate, Malan (a former South African military officer and respected African security analyst) titled his paper, 'AFRICOM: A Wolf in Sheep's Clothing'. Malan's main concern is that DoD officials continue to emphasise the non-military roles of AFRICOM, such as humanitarian assistance, civic action, and response to natural disasters, and this kind of 'messaging' has amplified African concerns about a militarisation of U.S. development policy and humanitarian assistance in Africa. 


\section{6}

For Malan, AFRICOM is being presented as a tool for integrating U.S. military, political, and humanitarian objectives under a unified military command. ${ }^{25}$

Malan's concern is that in Africa, mass displacement, hunger and disease is often the humanitarian fallout of political failures. In order to address such challenges effectively, there may be a need for military strength, political direction and humanitarian action, but this could not be done by integrating these elements under AFRICOM. "There can at best be good liaison between and perhaps coordination between humanitarian, developmental and military actors - but not integration." Moreover, Malan's concern is that in some parts of the world, like Iraq and Afghanistan, the face of U.S. foreign policy is clearly a military one, and that in Africa the DoD appears to be putting a civilian mask on the face of a combatant command with its marketing pitch for AFRICOM. ${ }^{26}$

Abel Esterhuyse, a South African academic and military strategist, likewise confirms that Africans are sceptical about AFRICOM. According to Esterhuyse, Americans should be open and transparent on their interests in Africa. Africa, he stresses, experiences a denial on the part of Americans concerning America's real strategic interests in Africa, and this is aggravated by an aggressive and militarised way of addressing problems in Iraq and Afghanistan. ${ }^{27}$ According to Esterhuyse, the problem is that the image of U.S. foreign policy in many parts of Africa is informed by U.S. military actions in other parts of the world, especially in Afghanistan and Iraq. This image is strongly associated with the U.S. military profile in general and that of an aggressive use of military force in particular. It also stands in stark contrast to efforts by DoD functionaries to attach a 'soft power' approach to AFRICOM and efforts to downplay a hard-core military role for the U.S. in Africa. A pertinent question is: how long will such 'soft-power' approach last before AFRICOM shows its true character and Africa or certain countries in Africa will be "Iraqed". ${ }^{28} \mathrm{He}$ also shares Malan's contention that Africans are afraid of the possibility that Americans would militarise their humanitarian action in Africa, and that American defence personnel may well play a significant role in such action. Esterhuyse furthermore points towards African concerns that AFRICOM is masked behind a humanitarian face in order to ensure a soft landing for the Command on the Africa continent. According to Esterhuyse, American humanitarian commitment could indeed be questioned in view of the U.S.'s inaction in past or recent humanitarian crises, such as those in Rwanda, Sierra Leone and Darfur (Sudan). Hence the question is whether the U.S. is not simply interested in pursuing and advancing its own interests on the African continent. ${ }^{29}$

Gerrie Swart, a political scientist at the University of South Africa, also asserts that there is a predominantly negative sentiment among African leaders about the 


\section{7}

establishment of AFRICOM. A great sense of reluctance to embrace the advent of AFRICOM exists, even though it is known and often pointed out that there is already a substantial American presence in Africa. This presence does not put African observers and analysts at ease, and African states in general continue to adopt a wary approach towards the establishment of AFRICOM. It is feared by some that AFRICOM will not only militarise U.S.-African relations, but also those African countries in which it will be located. This could even lead to greater support or sympathy for radical militants opposed to the U.S. and make Americans targets of violence. ${ }^{30}$ Swart further purports that the U.S. will find it difficult to convince Africans that America is unselfish. According to him, Americans would find it troublesome to defend AFRICOM's “altruistic approach” if the U.S.'s new strategic interest in Africa is merely working towards the advancement of U.S. interests. To this end, Americans will need to inform Africans of AFRICOM's intended projects by means of ongoing diplomacy in order to make this a viable and successful project. $^{31}$

The above-mentioned sentiments are also shared by other analysts on the African continent. Tidiane Sy, a journalist reporting from Dakar, Senegal, wrote that there is widespread scepticism about the role of AFRICOM. American interests are associated with the ongoing competition for resources, especially oil, which should be viewed against the background of competition between Japan, China and the U.S. Sy also reported that some observers are of the opinion that AFRICOM could militarise political problems on the African continent in the sense that the "threat of terrorism" could be used as a pretext by some governments to deal with internal political problems and dissatisfied communities as if these were tantamount to terrorism, and thus would deal with such challenges in a military way. In the words of Prof Ettanibi Alemika of the Jos University in Nigeria: "They would send troops rather than to negotiate". ${ }^{32}$

Kenneth Mpyisi, Director of the Institute for Security Studies in Addis Ababa and a former career diplomat with the Ugandan Foreign Service, outlines a somewhat more nuanced approach towards AFRICOM. He argues that the first argument is not on the form of AFRICOM, but rather on its motive and timing. The proponents of this view are interested in questions about why the need for AFRICOM, and why now? According to this view, AFRICOM is not only a smack on the continent's sovereignty, but an attempt by the U.S. to secure its own interests - specifically concerning the increased economic and strategic importance of Africa. The second argument basically implies that any outright rejection of AFRICOM would not be wise, considering the inability of Africa to respond to and sustain some of its peacekeeping and peace building missions. Therefore, African role-players 


\section{8}

should rather engage AFRICOM in a constructive manner that addresses the security concerns of both the U.S. and Africa. ${ }^{33}$

\section{Political responses}

Mpyisi argues that amidst concern and excitement about AFRICOM, there is a lack of concerted and unified response from the continent. ${ }^{34}$ Swart likewise purports that achieving consensus amongst Africa's leadership on AFRICOM could be very difficult. $^{35}$ However, thus far, the creation of AFRICOM has not been welcomed with open arms at the political level in Southern Africa. More armed U.S. soldiers are not welcome in Africa, said South African Defence Minister Mosiuoa Lekota on 29 August 2007. Briefing the media, he made it clear that the Southern African Development Community (SADC) defence ministers decided that no member states would host more armed U.S. soldiers. Lekota further indicated that this was also the continental position of the AU. Any country that allowed itself to become a base for AFRICOM would have to live with the consequences, Lekota warned. This could amount to neighbouring African countries refusing to cooperate with AFRICOM. According to Lekota,

Africa has to avoid the presence of foreign forces on its soil, particularly if any influx of soldiers might affect relations between sister countries ... nevertheless, the SADC has adopted a position that it would be better if the U.S. did it from a distance.

Shortly before these statements, Lekota apparently did not respond to U.S. requests for him to meet the AFRICOM commander, Army General William E. (Kip) Ward. ${ }^{36}$

In response to these negative sentiments, one could rightly argue that that much of what is currently perceived to be the 'African popular sentiment' on AFRICOM is the product of South Africa's position and regional influence, as opposed to the broader sentiments in different countries. However, Algeria and Libya earlier ruled out hosting AFRICOM after both countries made it clear to U.S. diplomats that they were opposed to the new Command being based in their countries or any of their neighbouring countries. ${ }^{37}$ In view of the above, it is clear that the initial political response from the African leadership to the establishment and future existence of AFRICOM has not been favourable. Only the Liberian President, Ellen Johnson-Sirleaf, openly favoured the creation of AFRICOM, although she has been under pressure from fellow Liberians to abandon her stance that Liberia could be willing to host the AFRICOM headquarters. ${ }^{38}$ Be that as it 
may, it is still early days and one could somehow find that support for AFRICOM might be in the interest of some African states but not others.

Functionaries in the Bush Administration and Pentagon officials seem to be acutely aware of the criticism on and scepticism about the creation of AFRICOM. "This is not about a scramble for the continent," said Theresa Whelan, Deputy Assistant Secretary for Defence for African Affairs. ${ }^{39}$ According to Ryan Henry, Principal Deputy Under Secretary for Defence for Policy, there are some myths about AFRICOM: that AFRICOM is to be an anti-terrorism unit, that AFRICOM is an attempt to counter Chinese influence on the continent, and that it is an effort to ensure access to resources, specifically oil. ${ }^{40}$ Whelan likewise asserted that some people believe that Americans are establishing AFRICOM solely to fight terrorism or to secure oil or to discourage China. "This is not true," she maintained. "Natural resources represent Africa's current and future wealth, but in an open-market environment," she continued. "AFRICOM is about helping Africans build greater capacity to assure their own security." 41

Shortly after the announcement of AFRICOM's intended establishment, Pentagon officials started to address and dispel what was considered to be misconceptions about the new command. It was especially stressed that AFRICOM would not be created -

- $\quad$ in response to Chinese presence on the African continent;

- $\quad$ solely for the effort of enhanced counterterrorism; and

- to secure resources, such as oil.

It has also been stressed that AFRICOM -

- will not result in large-scale deployment of U.S. forces on the African continent;

- will not result in a dramatic increase in financial resources devoted to Africa; and

- will promote regional security and stability while coordinating U.S. support for African leaders. ${ }^{42}$

These issues will be further explored in the section below.

\section{American strategic interests in Africa}

It has already been explained that traditionally the U.S. has not been a major player in the security environment of sub-Saharan Africa, relying instead on other 
role-players to provide outside assistance to African states. Today, it is appropriate to revisit this position. In the past years, American security and strategic analysts have urged for a re-evaluation and refinement of American strategy towards Africa. ${ }^{43}$ Since the early 2000s, it was argued that the U.S. seeks an Africa where Americans can do business and cooperate in resolving shared problems, but where the need for direct U.S. military involvement is minimal. Politically, the U.S. would like to see competent, accountable governance with regular, peaceful transfer of power. There should also be institutionalised methods for public input into open policymaking procedures. Furthermore, the rule of law should be the norm with respect to human rights and minorities. Economically, the U.S. would like to see sustainable, ecologically sound development in Africa. In security terms, the U.S. seeks peace and stability, and resolution of conflicts that cause complex emergencies, solutions to Africa's refugee problems, the building of sound civilmilitary relations with civilian control of the military, abandonment of proxy aggression, and military forces that are able to protect national security, but which are not an impediment to economic growth and development. ${ }^{44}$

It should be clear that the U.S. already has a military presence on the African continent, which is expected to be continued or expanded under AFRICOM. Firstly, since 2002, the Combined Joint Task Force - Horn of Africa (CJTF-HOA) has based roughly 1700 troops at Camp Lemonier in Djibouti. The task force is mainly focused on terrorist activities in the region, and was reportedly involved in tracing down leaders of Somalia's Islamic Courts in December 2006. Secondly, the TransSahara Counter-Terrorism Initiative (TSCTI) similarly focuses on counterterrorism. It seeks to dampen Islamic extremism and locate and eliminate terrorists by providing counterterrorist training programmes and weapons to North African states. Thirdly, the U.S. military has significantly expanded its naval presence in the Gulf of Guinea, a stretch of coastline between Nigeria and Angola where oil supplies are becoming of the utmost interest to the U.S. There are now continuous patrols in the region, up from almost no activity in 2004, while the U.S. also conducted security co-operation activities with a number of countries, including Angola, Ghana and the Democratic Republic of Congo. ${ }^{45}$

Whatever has been said about AFRICOM, one matter is certain: The intended establishment of AFRICOM officially reflects a refinement and should be viewed against the background of an evolution in U.S. policymakers' perceptions of American strategic interests in Africa. According to Mbachu, interplaying in West Africa specifically is a volatile mix of strategic minerals - oil, uranium and diamonds - and milieus where radical Islamic groups are a potential threat. Not only is the U.S. keen to protect its oil supplies from the Gulf of Guinea, it is also 


\section{1}

keen that uranium from Niger and diamonds from Sierra Leone and Liberia do not fall into the hands of militant organisations. This should be viewed against the background of reports of al-Qaida using the trade of diamonds controlled by rebels during Sierra Leone's civil war to funnel funds and evade official banking systems with the help of Liberia under Charles Taylor. U.S. interests in the region are furthermore increasingly of strategic importance, with oil found all along the Gulf of Guinea. Even inland in the desert, including the states of Niger, Chad and Sudan, significant oil activities are the order of the day and of great interest to the U.S. The U.S. has also shown concern about radical Islamic influences in parts of West Africa, where anti-Western sentiments are strong. All of these seem to have contributed to the US decision to set up an Africa Command. ${ }^{46}$

In a report submitted to the U.S. Congress, Lauren Ploch, analyst in African affairs at the Congressional Research Service states that five factors have shaped increased U.S. interest in Africa in the past decade: HIV/Aids, oil, global trade, armed conflict and terror. Specifically, as far as oil is concerned, Ploch points out that Africa recently surpassed the Middle East as the U.S.'s largest supplier of crude oil. While Nigeria has long been Africa's oil giant, Angola has in recent years become the ninth largest oil supplier to the U.S. Further, Equatorial Guinea, Gabon and the Congo Republic also produce hundreds of barrels every day. ${ }^{47}$

Nigeria is still Africa's largest supplier of oil and is the fifth largest global supplier of oil to the U.S. Instability in the Niger Delta region has reduced output by as much as 25 per cent at some point ${ }^{48}$ - which is clearly not in the American interest. In this context, analysts point out that the sub-Saharan Africa oil production surpassed 4 million barrels a day in 2000 - more than Iran, Venezuela or Mexico. Currently, the U.S. obtains about 16 per cent of its oil from sub-Saharan Africa - almost as much as from Saudi Arabia. And, according to intelligence projections, the proportion of African oil supplies to the U.S. will reach 25 per cent by 2015, surpassing the entire Persian Gulf. The vast majority of this will be exported to the U.S. from the Gulf of Guinea. Currently, all along Africa's Atlantic coast, exploration companies are boasting new offshore finds. Investment in West Africa by big U.S. companies - such as ExxonMobil and Chevron-Texaco, as well as by smaller ones, such as Amerada Hess and Ocean Energy - are about to total an estimated $\$ 10$ billion annually. The Bush-Administration is very much aware of this and some lobby groups with members of the U.S. oil industry are already considering the Gulf of Guinea as an area of vital interest. To this end, Walter Kantsteiner, Assistant Secretary of State for Africa, earlier declared: "African oil is of national strategic interest to us, and it will increase and become more important as we go forward". ${ }^{49}$ 


\section{2}

Furthermore, current U.S. security policy is driven in large part by the Global War on Terror, which the Bush Administration has identified as a top security priority. From a U.S. point of view, terrorist attacks on U.S. embassies in Dar es Salaam and Nairobi in 1998, on targets in Mombassa in 2002, and more recently in Algiers in 2007, have highlighted the threat of terrorism. DoD officials have emphasised the need to work with African role-players in this regard. Of primary concern is challenges posed by so-called 'ungoverned spaces', defined as physical or non-physical area(s) where there is an absence of state capacity or political will to exercise control. And this could arise or result from a variety of causes, including poor governance, external aggression, competing claims, internal revolt, and related factors. If left unattended or unaddressed, failed states, humanitarian disasters, and ungoverned areas could become safe havens for terrorists.

Finally, it has already been explained that Pentagon officials have maintained that AFRICOM is not created in response to Chinese presence on the African continent. Yet, this can not simply be ignored or discarded as a factor of relevance. According to Miller, China has grown at an average of 10 percent per annum and its economic power has raised the strongest challenge to U.S. political power since the threat of Eastern Europe as a power bloc during the Cold War period.

Global power configurations have seen China emerging as a countervailing pull to US dominance in multilateral institutions at the global level, as well as initiating bilateral arrangements with countries that allow them to sidestep US dominance, particularly in loan-dependent regions such as Africa... The Chinese challenge now presents the world with a potential turning point in global hegemonic forces. 50

China's economic links with Africa have been strengthened through the multilateral signing of the Beijing Declaration during the gathering of the ChinaAfrica Forum in Beijing in 2000. This declaration outlines a firm commitment between African countries and China for increased co-operation in economic and international affairs and actually created a new political and economic order between China and Africa. ${ }^{51}$ Much of this relates to China's growing economy and the need to secure concessions of strategic resources and minerals for the future benefit of its economy. Specifically, China's rapidly rising dependence on oil and insecurity in the Middle East inspired China to actively pursue and obtain new avenues of strategic resources on the African continent. Van Rooyen and Solomon attribute this to the following reasons: 
- Firstly, African oil is generally of a higher quality than oil from most other countries. Because African oil is very similar to China's domestic oil product, it enables China to use its present domestic refining capabilities.

- Secondly, African oil-producing countries tend to be highly indebted and impoverished, thereby raising the opportunity for oil concessions in return for financial, economic and military assistance.

- Thirdly, African oil reserves are still largely untapped with less fierce international competition or involvement. This affords many opportunities for China's state-run oil companies to invest in African countries' mining and refining capabilities.

- Finally, it is expected that by 2010 West Africa will produce one fifth of the world's oil output.

Thus it is no surprise that China's oil expropriation has seen a large increase in dependence and involvement with African oil. In fact, China's dependence on African oil is such that 25 per cent of imported oil comes from Africa, making it the second largest source of Chinese oil. ${ }^{52}$

Observers point out that Africa's oil wealth is all the more important now that China is investing huge sums of money on the continent. Angola, China's leading supplier of oil, for instance, has received at least $\$ 5$ billion in loans and credit in exchange for oil. ${ }^{53}$ Generally, the need for energy and raw materials has accompanied China's expansionary growth, fuelling increased Chinese investment on the African continent. Chinese investments reached $\$ 11,7$ billion in 2006, including investments in the manufacturing, trade, transport and agricultural sectors. $^{54}$

According to Obadina, the rapid growth in the flow of resources between China and Africa does indicate that China will increasingly rival Europe and the U.S. as Africa's key trading partner in the $21^{\text {st }}$ century. This is mirrored in the following statistics: In the first six years of this decade, trade between Africa and China increased from a little under $\$ 10$ billion to about $\$ 60$ billion in 2006. China has become Africa's third largest trade partner, and is set to soon rise to second largest. The Chinese government expects that bilateral trade will reach $\$ 100$ billion by $2010 .{ }^{55}$

Finally, it could be argued that as much as the birth of AFRICOM is not a direct result of Chinese strategic engagement in Africa, it is certainly of great relevance to current and future U.S. strategic interests in Africa. After all, U.S. policymakers have noted Africa's growing strategic importance to U.S. interests and among those interests is the growing importance of Africa's natural resources, 


\section{4}

particularly energy resources. AFRICOM's establishment will certainly increase the American profile and presence on the African continent and coincides with China's growing economy and the need to secure concessions of strategic resources and minerals for the future benefit of its economy. Thus Chinese involvement is not without consequences to the U.S. role and strategic involvement on the African continent. At the same time, from a U.S. and AFRICOM point of view, Washington could be expected to avoid any action that could spark American-Chinese conflict in Africa or even create the impression of fierce competition over scarce resources, influence and power. Moreover, the U.S. seems to be careful not to create a situation where competition over influence on the African continent would cause a rift between the U.S. and China. Following a visit to China, Deputy Assistant Secretary of Defence for East Asia, David Sedney, reported in a briefing to the Pentagon on 3 March 2008 that he had "very successful" discussions about AFRICOM and how the U.S. and China can work together with African nations and regional organisations.

We had discussions about Africa. We had a presentation on the formation of AFRICOM, and the Chinese gave us a presentation on their role in Africa... And we agree to continue discussions on Africa in the military field, and I think that's a very positive thing.

Sedney also stated that neither the U.S. nor China would like to see Africa as a forum for conflict or competition between the U.S. and China, but rather pursue cooperation with a view to addressing the many needs in Africa, including in the field of security. ${ }^{56}$

Generally, there is indeed much more to AFRICOM than securing oil supplies from Africa for the U.S. and it would, therefore, be a mistake to view and consider AFRICOM solely or narrowly against the background of U.S. strategic interest over strategic resources and minerals in a competitive international community. Rather, it could be argued that - despite current reservations on the African continent about any meaningful role for AFRICOM - the Command could indeed play a constructive multilateral role in Africa's security challenges in the near future, specifically in terms of strengthening U.S.-African security co-operation.

\section{Future U.S.-Africa security co-operation}

In view of the above, the pressing question is: where does this leave AFRICOM? Malan's suggestion is that beyond military counter-terrorism, AFRICOM should focus on two primary and unashamed military support roles, namely, firstly, defence-sector reform, including civil-military relations; and 


\section{5}

secondly, support to building African peacekeeping and standby capacity. This implies a role in building more professional armed forces and entrenching the democratic principle of civil supremacy over the military. Furthermore, this implies a demonstrable commitment by AFRICOM to provide long-term, sustainable support to developing African peacekeeping capabilities - for participating in UN peacekeeping, as well as AU and regional peacekeeping. "These roles are indeed envisioned by the DoD but they are not writ at this point," Malan argues. ${ }^{57}$ Against this background the establishment of an African Standby Force (ASF) is of special interest.

Significant progress was made in recent years with the development of a cohesive African peace and security system when African defence functionaries met in Addis Ababa in May 2003 where they agreed on the modalities of an ASF. ${ }^{58}$ The notion of an ASF is basically intended to institute a multi-national force empowered to intervene in serious conflicts around the troubled continent. The aim is to provide the AU and other role-players on the African continent with a firmer foundation for undertaking peacekeeping endeavours and thus to move towards a less ad hoc way of responding to crises than in past years. In terms of the AU policy framework, the ASF will be deployed under the auspices of the AU to intervene in border wars and internal conflict. Institutionally, it will consist of five sub-regionally-based brigades (3000 to 4000 troops each) in addition to a sixth, continental, formation based at the AU's headquarters at Addis Ababa, Ethiopia. This will provide the AU with a combined standby capacity of 15000 to 20000 peacekeepers towards 2010 as the target date. $^{59}$

The ASF clearly represents a serious political intention on the part of African leaders to set up a multi-national military force empowered to intervene in serious conflicts around the troubled continent. African leaders seem to be keen to avoid a repeat of genocide, such as in Rwanda in 1994, when extremists from the Hutu majority slaughtered an estimated 800000 minority Tutsis and Hutu moderates in 100 days of killings. Yet, more than mere political will and commitment is needed as peacekeeping operations are immensely costly affairs played out in messy theatres. A logistically related factor, such as adequate funding for airlift resources, is crucial in rapid deployment and indeed a cause for concern in the African context. With no airlift, virtually no peacekeeping operation is possible - to mention only one of many pressing operational factors. Currently, very few African states have any strategic lift capabilities worth mentioning. If the ASF is to be worthy of the 'standby' in its name, strategic lift and related logistical support in the field will have to be in place. ${ }^{60}$ 


\section{6}

Historically speaking, some challenges encountered by the now defunct Organisation of African Unity (OAU) dating back to the operation in Chad (1981) seem to remain challenges in the African context. Considering some of the most serious peacekeeping challenges that the AU had to deal with in Burundi and Sudan (Darfur) in recent years, it could be stated that the African continent is still battling with some of the 'old OAU challenges', most notably inadequate allocation of financial and logistical resources. While there is no lack of political support for the development of the ASF, valid concerns persist about the financial implications of implementing AU objectives.

Put differently, Africa's main security challenge is to mobilise sufficient resources to provide a secure, stable and well-governed environment that is underpinned by the rule of law, human rights and civil liberties. There are great expectations of the AU being able to rapidly deploy the long-desired ASF as a PanAfrican ideal. But recent peacekeeping experience has revealed that the AU suffers from a lack of strategic management capacity, it has no effective mechanisms for operational level mission management, has insufficient logistical support and ability to manage logistics, lacks capacity in communication and information systems, and is totally dependent on external partners. ${ }^{61}$ Hence, De Coning rightly argues that the $\mathrm{AU}$ and African regional organisations do not have the capacity to undertake complex peacekeeping operations on their own. ${ }^{62}$

This said, Solomon and Du Rand rightly argue that the focus of peacekeeping operations is shifting towards a more integrated approach, including reconstruction, development, stability, civilian involvement and humanitarian aspects. This integrated approach to peace on the African continent demands even more resources from a cash-strapped continent and, in turn, necessitates wider international support. In short, Africa cannot go it alone in providing the stability which is essential for development. ${ }^{63}$ In view of the above, Malan argues that AFRICOM could and should make a concerted effort to assist the $\mathrm{AU}$ in overcoming some of the "critical capacity gaps". ${ }^{64}$ Mpyisi likewise states that if the U.S. genuinely wishes to ensure the long-term stability in Africa, it should ensure full support for endogenous initiatives by supporting the African peace and security architecture and, in particular, the ASF. ${ }^{65}$

From the American side, not too much has been said about peacekeeping in Africa, but it is acknowledged that "[d]espite a willingness to participate in these (peacekeeping) operations, many African militaries lack the command and control, training, equipment, and logistics capability to effectively participate in such efforts". Clearly, the U.S. has recognised the need to enhance peacekeeping capabilities on the African continent. ${ }^{66}$ For AFRICOM this could indeed be a point 


\section{7}

of departure for strengthening U.S.-African security co-operation and to create new opportunities to bolster the capabilities of Africa role-players.

\section{Conclusion}

Although U.S. military engagement in Africa is by no means something new, the creation of AFRICOM is certainly of great interest and has heightened some serious concerns among African role-players and in the U.S. From a U.S. government point of view, there are undoubtedly a number of unresolved issues. These range from Congressional funding to the status of current military, economic, humanitarian, counterterrorism and information programmes in a number of African states. Politically speaking, the question is how the U.S. government would ensure that military efforts do not overshadow or contradict U.S. military and diplomatic efforts and objectives in Africa. ${ }^{67}$ Practically speaking, little more than the forging of initial partnerships and the establishment of its Africa-based headquarters or logistics hub in the region is likely in the immediate future.

From an African point of view, some observers question the timing of AFRICOM's birth as a few decades too late to make a lasting and decisive impact on the continent's burgeoning crises and development challenges. Some others are more optimistic and they adapt a better-late-than-never approach to the advent of a more coherent U.S. military approach on the continent. ${ }^{68}$ For the latter, the establishment of AFRICOM may well be promising in terms of a closer approach to U.S. military engagement with the continent. ${ }^{69}$ Moreover, it is still early days and one could somehow find that support for AFRICOM might be in the interest of some African states but not others. Djibouti, for instance, has different interests and concerns than other countries, like South Africa. After all, this explains Djibouti's decision to allow thousands of American soldiers on its soil to 'fight terrorism', while other countries are seemingly opposed to it.

For the U.S., ideally speaking, AFRICOM may become an important vehicle to sustain U.S. involvement in Africa and to contribute towards a more positive image of the U.S. and its military in Africa. At the same time, the creation of AFRICOM could raise Africa's strategic profile in the U.S. as well as other parts of the world. African militaries indeed stand to benefit from the creation of AFRICOM in terms of military-diplomatic opportunities and tangible means. At the same time, AFRICOM may be the first real test for sustainable U.S. involvement in Africa. ${ }^{70}$

In the final analysis, Swart is probably correct that much about the future of AFRICOM would depend on whether the U.S. could convince role-players on the African continent that there is indeed a genuine interest in ending conflict, insecurity 


\section{8}

and underdevelopment in Africa through the provision of sustained assistance to African countries - which implies that AFRICOM will be more than a project whereby only the U.S. stands to gain in the long term, ${ }^{71}$ and what is narrowly aimed at pursuing U.S. strategic interests on the African continent. In other words, the nature of the engagement and the manner in which AFRICOM will be presented to a seemingly not-so-receptive or sceptical African audience will be pivotal to whether or not AFRICOM will succeed. This implies that diplomacy will be critical in the new strategic approach towards Africa. ${ }^{72}$ At the same time, African role-players probably need to realise that there is a lot of criticism and even hostility when the U.S. talks about promoting its national interests in Africa, but at the same time, there is the expectation that the U.S. will provide assistance to Africa. It should be understood that the U.S., like any other nation, uses its resources to promote national interests, not out of altruism. This does not necessarily suggest that the U.S. wants to or should impose its will on Africa or that it wants to control the continent, but there must be some balance in which Africans recognise that the U.S. will only play an active role if doing so is in its national interest.

\section{Endnotes}

${ }^{1}$ Metz, Steven (2000), 'Refining American Strategy in Africa', in Strategic Studies Institute Report, February, p. 2.

2 Ibid, p. 3.

${ }^{3}$ A reference to failed states.

${ }^{4}$ Ploch, Lauren (2007), 'Africa Command: US Strategic Interests and the Role of the U.S. Military in Africa', in CRS Report for Congress, Prepared for Members and Committees of Congress, updated 6 July, pp. 1, 12.

5 Ibid, p. 1.

${ }^{6}$ Esterhuyse, Abel (2008), 'The Iraqization of Africa: Looking at AFRICOM from a South African Perspective', in Strategic Studies Quarterly, Spring 2008, p. 113.

${ }^{7}$ Pham, Peter (2007), 'Getting AFRICOM Right', in World Defence Review, 15 February, Available at http://worlddefencereview.com/pham021507.shtml. Accessed on 22 September 2007.

8 Swart (2007a), 'The Role of AFRICOM: Observer, Enforcer or Facilitator of Peace?', in Conflict Trends, no. 4, p. 10.

${ }^{9}$ Swart, Gerrie (2007b), 'The Rules of Engagement: The Pitfalls and Panaceas of the Pentagon's New African Command', in Centre for International Political Studies (CIPS) Electronic Briefing, no. 48, p. 2.

${ }^{10}$ Hanson, Stephanie (2007), 'The Pentagon's New Africa Command', in Council on Foreign Relations: A Resource for Nonpartisan Information and Analysis, 3 May. Available at www.cfr.org/publication/13255/. Accessed on 21 September 2007.

${ }^{11}$ Moeller, Robert (2007), 'U.S. Africa Command: Frequently Asked Questions.' Available at www.eucom.mil/africomFAQs.asp. Accessed on 21 September 2007. 
${ }^{12}$ Hanson, op cit.

${ }^{13}$ Moeller, op cit.

14 AFRICOM Public Affairs Office (2007), 'AFRICOM Subject of Article, in Military Review', 31 December 2007. Available at www.africom.mil/getArticle.asp?art=1609. Accessed on 11 January 2008.

${ }^{15}$ Ploch, op cit, p. 2.

${ }^{16}$ Moeller, op cit.

${ }^{17}$ Ploch, op cit, p. 1.

${ }^{18}$ Ibid, p. 1.

${ }^{19}$ Ibid, p. 8.

${ }^{20}$ Ward, William, E., (2008), 'Questions and Answers About AFRICOM.' Available at www.africom.FAQ.asp. Accessed on 5 March 2008.

${ }^{21}$ Esterhuyse (2008), op cit, p. 120.

${ }^{22}$ Hanson, op cit.

23 Munson, Robert (2008), 'Do We Want to "Kill People and Break Things" in Africa: A Historian's Thoughts on Africa Command', in Strategic Studies Quarterly, Spring 2008, p.97.

${ }^{24}$ Ibid, p. 109.

25 Malan, Mark (2007), 'AFRICOM: A Wolf in Sheep's Clothing,' Testimony by Mark Malan, Refugees International, before the Subcommittee on African Affairs, Committee on Foreign Relations, U.S. Senate, at the Hearing entitled 'Exploring the U.S. Africa Command and a New Strategic Relationship With Africa', 1 August, p. 1 .

${ }^{26}$ Ibid, pp. 2-3.

${ }^{27}$ Esterhuyse, Abel (2007), 'Dis wat Afrika die Amerikaners wil vra' (This is what Africans would like to ask Americans), in Rapport: Perspektief, 16 September, p. 2.

${ }^{28}$ Esterhuyse (2008), op cit, pp. 120-122.

${ }^{29}$ Esterhuyse (2007), op cit, p. 2.

${ }^{30}$ Swart (2007a), op cit, p. 14.

${ }^{31}$ Swart, Gerrie (2007c), 'Hoe welkom en suksesvol sal VSA se AFRICOM wees?' (How welcome and successful would U.S.'s AFRICOM be?), in Die Burger, 6 September, p. 15.

32 Sy, Tidiane (2007), 'Wat maak Grootboet in Afrika' (What is Big Brother doing in Africa?), in Die Burger, 6 September, p. 15.

${ }^{33}$ Mpyisi, Kenneth (2007), 'US Involvement in African Peacekeeping', in Conflict Trends, no. 4, pp. 35-36.

${ }^{34}$ Ibid, p. 36.

${ }^{35}$ Swart (2007a), op cit, p. 14.

${ }^{36}$ Hartley, Wyndham (2007), 'Southern Africa: More U.S. Soldiers Not Welcome in Africa, says Lekota', in Business Day, 30 August. Available at http://allafrica.com/stories/20070830344.html. Accessed on 22 September 2007.

${ }^{37}$ Swart (2007b), op cit, p. 2.

${ }^{38}$ Sy, op cit, p. 15.

${ }^{39}$ Hanson, op cit.

${ }^{40} \mathrm{Sy}$, op cit, p. 15. 
41 Kruzel, John J (2007), 'Pentagon Official Describes AFRICOM's Mission, Dispels Misconceptions', in American Foreign Press Service, 3 August. Available at www.defencelink.mil/news/newsarticle. $\operatorname{aspx} ? \mathrm{id}=46931 \& 446931=20070803$.

Accessed on 22 September 2007.

${ }^{42}$ Crawley, Vince (2007), 'U.S. Military's Africa Command: Officials Say New AFRICOM Will Emphasize Humanitarian Missions, Civil Affairs', in African Armed Force Journal, April, p. 9.

${ }^{43}$ See for instance Metz, op cit.

${ }^{44}$ Metz, op cit, pp. 13-14.

${ }^{45}$ Hanson, op cit.

${ }^{46}$ Mbachu, Duleu (2007), 'Africa's Unfolding Desert War', in ISN Security Watch, 7 November, p. 1.

${ }^{47}$ Ploch, op cit, p. 13; Crawley, Mike (2007), 'With Mideast Uncertainty, US Turns to Africa for Oil', in The Christian Science Monitor, 23 May. Available at www.csmonitor.com/2002/0523/p07s01-woaf.html. Accessed on 22 September 2007.

${ }^{48}$ Ploch, op cit, p. 13.

${ }^{49}$ Crawley, op cit.

${ }^{50}$ Miller, Darlene (2007), 'South Africa and the 'New Bandung', Inside AISA: The Bimonthly Newsletter of the Africa Institute of South Africa, May, p. 9.

${ }^{51}$ Van Rooyen, Jan, and Solomon, Hussein (2007), 'The Strategic Implications of the US and China's Engagement Within Africa', Scientia Militaria, vol. 35, no. 1, p. 9.

52 Ibid, pp. 9-10.

${ }^{53}$ Perry, Alex, and Eisenstein, Zoe (2007), 'Two Sides of Africa's Coin', Time, 26 November, p. 39.

${ }^{54}$ Miller, op cit, p. 9.

55 Obadina, Tunde (2007), 'Who's Afraid of China's Ties With Africa?', in Africa Today, August 2007, p. 33.

${ }^{56}$ Sedney, David (2008), 'Transcript: U.S. and China Discuss Africa Command and Working Together in Africa.' Available at www.africom.mil/getArticle.asp? $=1668$. Accessed on 5 March 2008.

${ }^{57}$ Malan, op cit, pp. 5-6.

58 De Coning, Cedric (2004), 'Towards a Common Southern Africa Peacekeeping System', in CIPS Electronic Briefing Paper, no. 16, p. 4.

59 Thorne, EA (2003), 'The African Standby Force Takes Shape: An Observation of Needs and Necessary Actions', in African Armed Forces Journal, July, p. 26.

60 Solomon, Hussein, and Du Rand, Amelia (2006), 'Constraints in African Peacekeeping: The Need for a United Nations Emergency Peace Service (UNEPS) ', in CIPS Electronic Briefing Paper, no. 75, pp. 1-2.

${ }^{61}$ Malan, op cit, pp. 6-7.

${ }^{62}$ De Coning, Cedric (2004), 'Refining the African Standby Force Concept', in Conflict Trends, no. 2, pp. 22-23.

${ }^{63}$ Solomon and Du Rand, op cit, pp. 2, 6.

${ }^{64}$ Malan, op cit, p. 7. 
${ }^{65}$ Mpyisi, op cit, p. 40.

${ }^{66}$ Ploch, op cit, pp. 14-15.

${ }^{67}$ Pincus, Walter (2007), 'U.S. Africa Command Brings New Concerns', in Washington Post.com, 28 May. Available at www.washingtonpost.com/wpdyn/content/article/2007/05/27/AR2007052700978.html. Accessed on 10 January 2008.

${ }^{68}$ Swart (2007b), op cit, p. 5.

${ }^{69}$ Malan, op cit, pp. 5-7.

${ }^{70}$ Esterhuyse (2007), op cit, pp. 125-127.

${ }^{71}$ Swart (2007b), op cit, p. 5.

${ }^{72}$ Swart (2007a), op cit, p. 14. 